\title{
Intervention of High Density Plantation of Mango in Lower Hills for Doubling the Farmers' Income
}

\author{
Pankaj Nautiyal*, Gaurav Papnai, Neeraj Joshi, Varun Supyal and Ritika Bhaskar \\ Krishi Vigyan Kendra (ICAR-VPKAS), Chinyalisaur, (Uttarkashi) Uttarakhand, India \\ *Corresponding author
}

\begin{tabular}{|c|}
\hline Keywords \\
\hline $\begin{array}{l}\text { High Density } \\
\text { plantation, } \\
\text { Mango in Lower } \\
\text { Hills }\end{array}$ \\
\hline Article Info \\
\hline $\begin{array}{l}\text { Accepted: } \\
07 \text { January } 2021 \\
\text { Available Online: } \\
\text { 10 February } 2021\end{array}$ \\
\hline
\end{tabular}

Concept of high density plantation has become extremely significant to increase fruit yield and productivity in small as well as scattered land. Amrapali cultivar of mango showed good performance in terms of yield and quality. Under high density plantation system, in Amrapali cultivar, maximum productivity and profitability was obtained. The plantation with normal density plantation fetches net return of Rs. 244800 per ha, whereas, plantation with high density obtained Rs. 532700 per ha. The net return per nail in HDP in lower hills is more than double the traditional method and this profit may be fetched four years earlier. The high net return is due to high density plantation and late season harvesting in lower hills. Mango is harvested in this area in first fortnight of August when the mango of plain area is almost over. Therefore, off season production fetches more returns as compared to main mango season.

\section{Introduction}

Mango (Mangifera indica L.) is the most important fruit in India. It has been rightly termed as "King of fruits" because of wide adaptability, delicious taste, high nutritional value, cultural and religious importance. It has rich potential for employment and income generation. India occupies pride of place in terms of mango production in the world as it is the largest producer of mango. The country is known for producing choicest cultivars of mango, with commercial production of about 40 cultivars. The main cultivars are Alphanso, Banganpalli, Neelam, Totapuri, Kesar, Himsagar, Dashehri, Langra, Chausa,
Amrapali etc., most of which are region specific. At present, quality production of mango suffer from several limiting factors like low adoption of scientific management practices, biennial bearing, incidences of insect pest, diseases and physiological disorders, high acreages under seedling plantation and verities with low yield potential, etc.

Mango is successfully grown in Andhra Pradesh, Uttar Pradesh, Odisha, Karnataka and Bihar, which covers almost $50 \%$ of total area and $60 \%$ of the total mango production. In India it is cultivated on 2291 thousand ha with production of 20444 thousand MT and 
productivity of $8.92 \mathrm{MT} / \mathrm{ha}$ (National Horticulture Board, 2020). In Uttarakhand alone, the mango was cultivated on 36.48 thousand ha of land yielding 152.71 thousand MT of fruit annually. As per the statistical data the mango crop area in Uttarkashi district is about 235 haand the production is only 350MT. (Sate Horticulture Mission Government of Uttarakhand. 2020). Mango in Uttarakhand state is grown in the plain areas such as U S Nagar, Haridwar and valley area of Dehradun, Nainital, Pauri and Almora districts. The main varieties grown in these districts are Dashehri and Langra. At present, in these areas mango is cultivated largely through traditional systems and at wider spacing due to large tree canopy, thereby, requiring high inputs. Moreover, in this system mango tree takes 5-6 years in contrast to 2-3 years for high density for coming into commercial bearing and thus maximize the overall cost of production per unit area. The available land area for fruit cultivation is shrinking due to urbanization and industrialization and it is difficult to achieve the desired level of production per unit area under presently adopted traditional systems. Amrapali mango grown in High density plantation, productivity per unit area will be high due to higher plant population per unit area and will give better economic returns (Singh et al., 2001).The efficient training and pruning can maintain the proper canopy size of the fruit tree, improve fruit quality and provide opportunity to increase the number of trees per unit area (Nautiyal et al., 2016). The pruning in high density orchards is prerequisite to maintain the desired canopy of this fast growing plants (Nautiyal et al., 2020).

Intervention of high density plantation of Amrapali variety of Mango in Lower Hills

Uttarakhand by and large is hilly and the agro climatic conditions found in the large part of the state restrict the cultivation of field crops but offer great scope for the development of horticultural industry. Generally in hilly area of the state was known for the production of temperate fruits but in the recent past, mango cultivation has gained momentum in lower hills. Under such circumstances the concept of high density plantation has become extremely significant to increase fruit yield and productivity in small as well as scattered land. Amrapali cultivar of mango showed good performance in terms of yield and quality under Tarai regions of Uttarakhand (Singh et al., 2015).

\section{Technical inputs}

Krishi Vigayn Kendra, Uttarkashi introduced the intervention of high density plantation of Amrapali variety of mango in lower hills of district Uttarkashi. The dwarf variety of mango Amrapali was planted in $3 \times 3 \mathrm{~m}$ spacing at farmer's field. A total number of 44 plants were planted in $400 \mathrm{~m}^{2}$ (2Nali) area where if we would have planted the large varieties (Dashehri/ Langra) it would be maximum 8 plants in this area. High density plantation can accommodate more tress (1600, 800, 400 and 266 tress/ha) in comparision to traditional cultivation (100 trees/ha) hence, gives more yield (Adak et al., 2019). This intervention was implemented in five farmers' field. The first harvesting of fruits was taken after $3^{\text {rd }}$ year of plantation where in case of large varieties it would be more than 7 to 8 years.

The pits are dug $100 \mathrm{~cm}^{3}$ during the month of June and filled with $25 \mathrm{~kg}$ well rotten FYM and soil. The time of planting is beginning of monsoon. During planting, earth ball should remain intact and graft union above the ground level. In the initial 2-3 years, it is advisable to protect plants against frost and low temperature injury by covering plants and resorting to flood irrigation. In first year, in 
non bearing trees, apply $70 \mathrm{~g}$ Nitrogen, $100 \mathrm{~g}$ Phosphorous and $50 \mathrm{~g}$ Potash. The above doses are multiply with the age of the tree. The recommended doses of fertilizers should be applied twice in a year i.e. beginning of monsoon (June-July) and after the fruit harvesting (September), whereas, apply FYM in single dose during the month of September. The first harvesting of fruits is taken after $3^{\text {rd }}$ year of plantation.

Table.1 Comparison of economic analysis between Normal and high density plantation of mango

\begin{tabular}{|c|c|c|c|c|c|c|c|c|c|c|}
\hline $\begin{array}{c}\text { Planting } \\
\text { system }\end{array}$ & Spacing & $\begin{array}{c}\text { plants/ } \\
\text { ha }\end{array}$ & variety & $\begin{array}{c}\text { Year of } \\
\text { first } \\
\text { fruiting }\end{array}$ & $\begin{array}{c}\text { Cost of } \\
\text { Cultivation/ } \\
\text { ha }\end{array}$ & $\begin{array}{c}\text { Yield } \\
\text { q/ha }\end{array}$ & $\begin{array}{c}\text { Rate/ } \\
\text { kg }\end{array}$ & $\begin{array}{c}\text { Gross } \\
\text { Return/ha }\end{array}$ & $\begin{array}{c}\text { Net } \\
\text { Return/ha }\end{array}$ & $\begin{array}{c}\text { Net return/ } \\
\text { Nali }^{\#}\end{array}$ \\
\hline $\begin{array}{c}\text { Normal } \\
\text { density }\end{array}$ & $7 \times 7 \mathrm{~m}$ & 204 & Dasheri & $7^{\text {th }}$ year & 61200 & 153 & 20 & 306000 & 244800 & 4896 \\
\hline $\begin{array}{c}\text { High } \\
\text { Density }\end{array}$ & $3 \times 3 \mathrm{~m}$ & 1111 & Amrapali & $3^{\text {rd }}$ year & 133320 & 222 & $30 *$ & 666000 & 532680 & 10654 \\
\hline
\end{tabular}

(*The high rate mention due to off season harvesting, ${ }^{\#} 1 \mathrm{ha}=50 \mathrm{Nali}$ and 1 Nali $=200 \mathrm{~m}^{2}$ )

Plate.1 High Density orchard of mango variety Amrapali at Village Chupaliya (Uttarkashi)

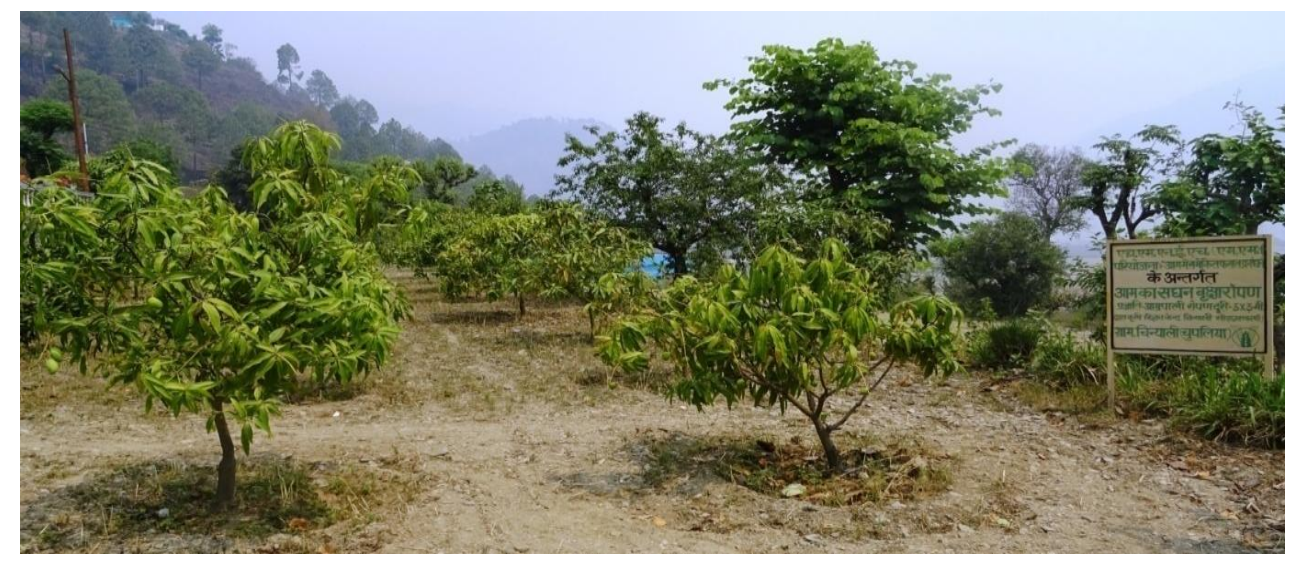

Plate.2 KVK Uttarkashi giving technical advice to Mango farmer

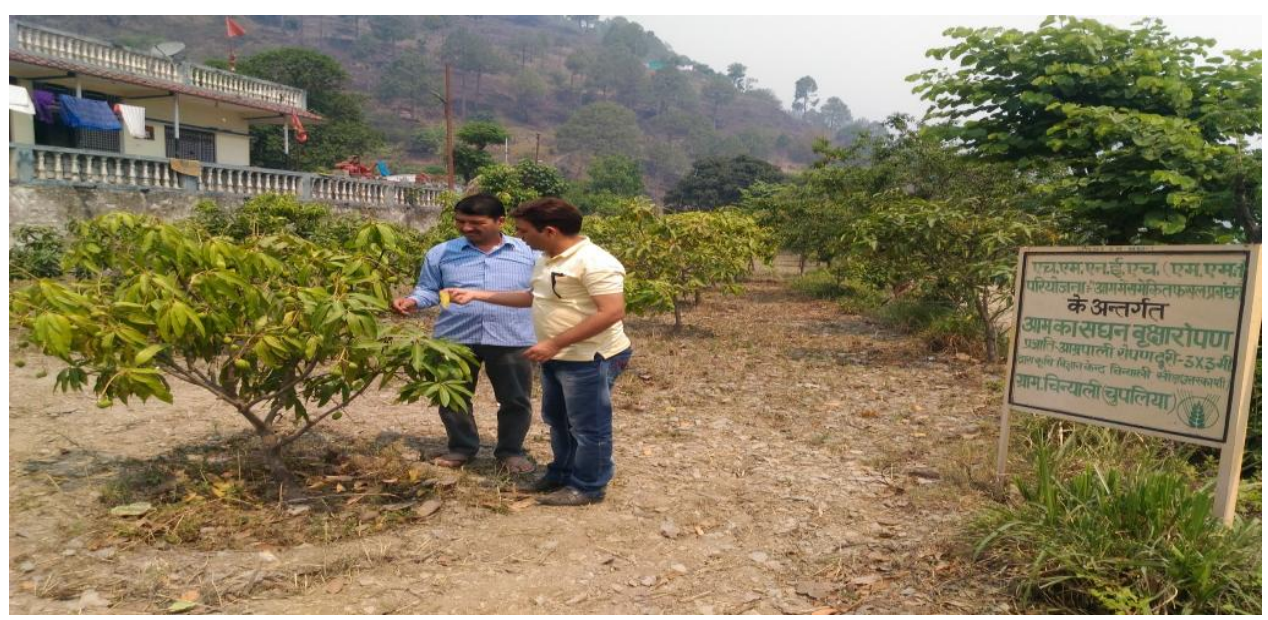




\section{Outcome of the Technology}

The plantation with normal density plantation fetches net return of Rs. 4896/Nali, whereas, plantation with high density obtained Rs. 10654/Nali. The net return per nail in HDP in lower hills is more than double the traditional method and this profit may be fetched four years earlier. The high net return is due to high density plantation and late season harvesting in lower hills. The comparison of economic analysis depicts in the present table 1 that the plantation with normal density plantation fetches Rs. 244800/ha., whereas, plantation with high density obtained Rs. 532680/ha. Fruit yield obtained 25.00 and 26.72 quintal/ha from Amrapali under high density system (Yadav et al., 2011). Under high density plantation system, in Amrapali cultivar, maximum productivity and profitability was obtained (Sharma et al., 2016) recorded Mango is harvested in this area in first fortnight of August when the mango of plain area is almost over. Therefore, off season production fetches more returns as compared to main mango season.

In the hope of good monitory benefit others farmers are getting attracted towards mango farming. Now, in this area more than 10 orchards have been successfully planted. This successful intervention may be taken up in other lower hills of hilly states and play a crucial role to double the farmers' income.

\section{References}

Adak T., Mishra D., Kumar K. and Singh V.K.2019. Analysis of soil and tree productivity under high density planting system in mango cv. Dashehari (Mangifera indica L.). Tropical Plant Research 6(1): 24-30.

National Horticulture Board. 2020. Indian Horticulture database 2019-20. National
Horticulture

Board,http://nhb.gov.in/StatisticsViewer. aspx?Type=HC2\&menu.Menu=144Acce ssed January 6, 2021.

Nautiyal P, Lal S, Dimri D C and Arora I. 2016. Shoot pruning severity in high density of guava (Psidium guajava L.). International Journal of Agriculture Sciences, 8(52):2427-2431.

Nautiyal P, Lal S, Papnai G, Joshi N and Supyal V. 2020. Pruning Severity in High Density Guava for Higher Returns. International Journal of Current Microbiology and Applied Sciences, 9(09): 2704-2716. doi: https://doi.org/10.20546/ijcmas.2020.909 .337

Sate Horticulture Mission Government of Uttarakhand.2020. Horticulture Production data 201920.https://shm.uk.gov.in/files/Horticultur e_Production_Data_2019-20.pdf, accessed January 8, 2021.

Singh A. K., Pandey Y. and Mishra N. K. 2015. Evaluation of hybrids and selections of mango (Mangifera indica L.) under Tarai region of Uttarakhand. Progressive Horticulture, 47(1).

Sharma R., Jain P. K and Sharma T. R. 2016. Improvement in productivities and profitability in high density orchard of mango (Mangifera indica L) cv. Amrapali through integrated nutrient. Economic Affairs61(3): 533-538.

Singh S., Yadav G. S., Singh J. and Hoda M.2001. High density planting system in 'Amrapali' mango (Mangifera indica). IndianJournal of Agricultural Sciences 71 (6): 381-3.

Yadav A.K., Singh J. K and Singh H. K. 2011. Studies on integrated nutrient management in flowering, fruiting, yield and quality of mango cv. Amrapali under high density orcharding. Indian Journal of Horticulture, 68: 453-460. 


\section{How to cite this article:}

Pankaj Nautiyal, Gaurav Papnai, Neeraj Joshi, Varun Supyal and Ritika Bhaskar. 2021. Intervention of High Density Plantation of Mango in Lower Hills for Doubling the Farmers' Income. Int.J.Curr.Microbiol.App.Sci. 10(02): 696-700.

doi: https://doi.org/10.20546/ijcmas.2021.1002.083 